\title{
Pengaruh Kecemasan Matematika dan Gender Terhadap Kemampuan Penalaran Adaptif Matematika Siswa SMP Negeri 2 Kendari
}

\author{
(The Effect Of Mathematics Anxiety And Gender On The Students' Adaptive Mathematic \\ Reasoning Ability At SMP Negeri 2 Kendari)
}

\author{
Rahmat Wijaya ${ }^{1}$, Fahinu' ${ }^{2}$, Ruslan ${ }^{3}$ \\ ${ }^{1}$ Alumnus Prodi Pendidikan Matematika PPs Universitas Halu Oleo \\ ${ }^{2}$ Dosen Pendidikan Matematika FKIP dan PPs Universitas Halu Oleo ; Co-author: fahinu@uho.ac.id \\ ${ }^{3}$ Dosen FMIPA dan Pendidikan Matematika PPs Universitas Halu Oleo
}

\begin{abstract}
Abstrak: Penelitian ini bertujuan untuk menganalisis pengaruh kecemasan matematika dan gender terhadap kemampuan penalaran adaptif matematika siswa yang dilakukan di SMP Negeri 2 Kendari. Metode yang digunakan adalah kausal komparatif dengan rancangan two factorial. Pengambilan sampel dilakukan dengan Purposive Sampling untuk menentukan kelas yang digunakan kemudian dilanjutkan dengan Stratified Random Sampling untuk menentukan jumlah sampel siswa laki-laki dan perempuan. Hasil penelitian ini menunjukkan bahwa : 1) adanya perbedaan pengaruh kemampuan penalaran adaptif matematika antara siswa laki-laki dengan siswa perempuan, dimana rata-rata nilai siswa perempuan lebih tinggi dari siswa laki-laki., 2) adanya pengaruh kecemasan matematika terhadap kemampuan penalaran adaptif matematika, dimana jika skor kecemasan matematika mengalami kenaikan maka kemampuan penalaran adaptif matematika akan ikut meningkat, dalam hal ini semakin tinggi skor kecemasan matematika maka semakin rendah tingkat kecemasannya dan sebaliknya., 3) Adanya pengaruh kecemasan matematika dan gender secara simultan terhadap kemampuan penalaran adaptif matematika, dimana secara parsial hanya faktor kecemasan matematika yang memberikan pengaruh terhadap kemampuan penalaran adaptif matematika.
\end{abstract}

Kata kunci: Kecemasan Matematika, Gender, dan Kemampuan Penalaran Adaptif Matematika.

\begin{abstract}
This study aimed to analyze the effect of mathematics anxiety and gender on the students' adaptive mathematic reasoning ability at SMP Negeri 2 Kendari. The study employed a causal comparative method with two factorial design. Samples were determined using the purposive sampling to select a class, followed by the stratified random sampling to determine the number of male and female sample students. Results of the study showed that: 1) there was a different effect of adaptive mathematic reasoning ability on different gender, with females scoring higher than male; 2) there was an effect of mathematics anxiety on adaptive mathematic reasoning ability, as an increase in mathematics anxiety is always followed by an increase in adaptive mathematic reasoning ability as well, and vice versa; 3) there was an effect of mathematics and gender simultaneously on adaptive mathematic reasoning ability, and partially only mathematics anxiety factors had an effect on adaptive mathematic reasoning ability.
\end{abstract}

Keywords: Mathematics Anxiety, Gender, Adaptive Mathematic Reasoning Ability.

\section{PENDAHULUAN}

Mempelajari matematika akan
melatih seseorang untuk memiliki
kemampuan berpikir secara kritis, logis,
analitis, kreatif dan sistematis.
Kemampuan tersebut akan mempengaruhi
seseorang dalam mengambil keputusan
diberbagai permasalahan hidupnya.
Dengan kata lain, dengan mempelajari
matematika akan mempengaruhi kualitas
hidup dan sumberdaya manusia yang siap menghadapi tantangan hidup dari perkembangan zaman.

NCTM (National Council of Teacher Mathematics) sebagai sebuah lembaga yang bergerak dalam bidang penggembangan kurikulum pembelajaran matematika di Amerika Serikat, menyatakan bahwa pemecahan masalah harus menjadi fokus pada kurikulum matematika di sekolah (Sobel, 2004:60). Hal tersebut karena pemecahan masalah 
adalah tujuan yang prinsipil dalam proses pembelajaran, yaitu untuk mengembangkan keinginan berpikir.

Proses berpikir dalam pemecahan masalah sudah seharusnya mendapatkan perhatian para pendidik terutama untuk mengembangkan siswanya agar terbiasa berpikir secara logis. Cooney et al. dalam Hudojo (2005:126) menyatakan bahwa mengajarkan siswa untuk menyelesaikan masalah memungkinkan siswa itu menjadi lebih analitik dalam mengambil keputusan didalam kehidupan, sebab siswa akan terbiasa untuk mengumpulkan informasi yang relevan, menganalisis informasi, dan meneliti kembali hasil yang diperolehnya. Dengan demikian tidak disalahkan jika ada sebuah ungkapan yang menyatakan bahwa pemecahan masalah adalah jantungnya matematika (heart of mathematics).

Masalah-masalah yang berhubungan dengan matematika sering dijumpai pada situasi sehari-hari. Permasalahan matematika yang berkaitan dengan kehidupan nyata biasanya dituangkan melalui soal-soal yang berbentuk cerita. Penyajian matematika dalam bentuk cerita merupakan salah satu fungsi matematika sebagai aktivitas manusia, karena dalam soal cerita terdapat pengalamanpengalaman siswa yang berkaitan dengan konsep matematika (Tambunan, 1999, 18). Dalam penyelesaian soal cerita terlebih dahulu siswa harus dapat memahami isi soal cerita tersebut, setelah itu menarik kesimpulan obyek-obyek yang harus dipecahkan dan memisalkannya dengan simbol-simbol matematika, sampai pada tahap akhir yaitu penyelesaian (Indarwati, 2012:1).

Hasil penelitian Killpatrick, dkk (2001: 26) terdapat lima kompetensi matematika yang perlu dikembangkan dalam pembelajaran matematika di sekolah, yaitu: conceptual understanding (pemahaman konsep), proceduralfluency (kemahiran prosedural), strategic competence (kompetensi strategis),adaptive reasoning (penalaran adaptif), dan productive disposition (sikap produktif) (Killpatrick, dkk., 2001:130). Penalaran merupakan salah satu kecakapan matematika yang tidak dapat dipisahkan dari kecakapan matematika lainnya, terutama pemecahan masalah.

Bernalar sebagai proses pemecahan masalah tidak sejalan dengan kualitas kemampuan untuk menyelesaikan sebuah masalah - masalah yang sesungguhnya. PISA (Programme of International Assessment), yang memperlihatkan prestasi Matematika Indonesia selalu berada pada level bawah. Hasil PISA periode tahun 2003 menempatkan Indonesia pada peringkat 38 dari 41 negara, hasil PISA periode tahun 2006 menempatkan Indonesia pada peringkat 50 dari 57 negara, hasil PISA periode tahun 2009 menempatkan Indonesia pada peringkat 60 dari 65 negara, dan berdasarkan hasil PISA terakhir yaitu pada tahun 2011 Indonesia berada pada peringkat nomor 2 dari bawah atau peringkat ke-66 dari 67 negara yang ikut (Subanindro, 2012: 810).

Berkenaan dengan rendahnya kemampuan pemecahan masalah siswa Indonesia, maka peningkatan kualitas pembelajaran Matematika jelas perlu dilakukan. Menurut Hayat (2010: 27), abad sekarang dan kehidupan masa depan, kemampuan dalam berhitung jelas tak cukup lagi. Pada benchmark internasional diungkapkan bahwa kompetensi membaca, menulis, dan berhitung yang biasa disebut 3R (Reading,wRiting, dan aRithmethic) memang masih penting, namun ada kompetensi lain yang justru lebih utama saat sekarang yaitu kemampuan bernalar (reasoning). Dengan kata lain, gagasan 3R seharusnya diubah menjadi 4R dengan menambahkan Reasoning dalam kompetensi dasar siswa (Hayat, 2010: 27). Implementasi pembelajaran yang menekankan kehadiran penalaran juga telah direkomendasikan oleh NCTM dengan menyatakan bahwa penalaran 
merupakan bagian dari kegiatan belajarmengajar matematika (Ibrahim, 2011: 6).

Penalaran sebagai pondasi matematika perlu ditingkatkan karena jika kemampuan penalaran tidak dikembangkan pada siswa, maka matematika hanya menjadi masalah bagi siswa saat mengikuti serangkaian prosedur dan meniru contoh tanpa berpikir bahwa matematika itu masuk akal (Susanti, 2012: 290). Kemampuan penalaran merupakan hal yang penting untuk dikuasai siswa karena sangat berkaitan dengan pengambilan keputusan terhadap setiap masalah yang dihadapi siswa (Ardiansyah, 2011:3).

Rendahnya kemampuan penalaran matematis siswa mengindikasikan masih rendahnya kemampuan penalaran adaptif siswa. Hal ini karena kemampuan penalaran adaptif merupakan bagian dari kemampuan penalaran (Killpatrick, dkk., 2001: 129).

Rendahnya kemampuan penalaran matematika siswa, bisa disebabkan oleh beberapa faktor, baik itu faktor eksternal maupun faktor internal siswa. Faktor eksternal adalah faktor yang berasal dari luar diri siswa, seperti metode atau strategi pembelajaran. Sementara itu faktor internal adalah faktor yang berasal dari dalam diri siswa, seperti emosi dan sikap terhadap matematika. Faktor internal memiliki peranan yang cukup besar dalam kemampuan penalaran matematika. Hal tersebut disebabkan karena pemecahan masalah matematika itu sendiri, yang bersifat tidak rutin dan membutuhkan tingkat pemahaman dan penalaran yang tidak sederhana. Sehingga dapat menimbulkan konflik dalam diri siswa. Penelitian Lyons dan Beilock dalam Dzulfikar (2013:47) menunjukkan bahwa masalah-masalah matematis dapat menyebabkan otak menjadi sakit.

Penelitiaan yang saat ini banyak dilakukan, lebih fokus pada metode atau strategi pembelajaran saja dan masih sangat sedikit yang melakukan penelitian secara spesifik terhadap faktor internal siswa dalam kemampuan penalaran, walaupun realita menunjukan rendahnya kemampuan bernalar dalam proses pemecahan masalah matematika diperparah dengan kenyataan ketidaksukaan siswa terhadap matematika itu sendiri. Selain itu, sebagian besar siswa menganggap matematika adalah mata pelajaran yang sulit dipelajari dan menakutkan. Rasa takut yang timbul tersebut dapat menimbulkan kecemasan saat siswa sedang belajar atau berinetaksi dengan matematika atau biasa dikenal dengan kecemasan matematika (mathematics anxiety) (Ashcraft, 2002:1).

Kecemasan merupakan suatu bentuk perasaan takut dan khawatir yang tidak menyenangkan, tidak jelas dan bersifat menyebar. Johnson dalam Desmita (2010:298) memperkirakan 10\% hingga $30 \%$ anak remaja sangat cemas disekolah dan cukup mengganggu prestasi belajarnya. Sama seperti halnya jika seseorang merasa cemas terhadap pelajaran matematika. Zakaria \& Nurdin (2008:27) menyatakan bahwa kecemasan siswa yang tinggi terhadap pelajaran matematika akan berpengaruh pada prestasi belajar siswa. Pengaruh negatif tersebut pada dasarnya timbul karena sifat materi matematika itu sendiri. Dimana matematika untuk kebanyakan siswa dianggap sebagai materi yang bersifat abstrak, rumit dan membutuhkan kemampuan khusus serta waktu yang tidak sebentar dalam menyelesaikannya, khususnya pemecahan masalah matematika yang bersifat tidak rutin.

Siswa yang tidak mudah paham dengan masalah biasanya akan mengalami rasa cemas. Terdapat dua kemungkinan terhadap siswa yang cemas tersebut. Pertama siswa akan cuek dan bersikap acuh dengan tugas matamatika yang diberikan, kedua siswa akan berusaha semaksimal mungkin untuk memahami matematika. Namun hal tersebut dapat meningkatkan rasa cemas mereka saat 
tidak kunjung ditemukan penyelesaian. Wicaksono dan Saufi (2013:12) menyatakan rasa cemas yang meningkat akan memperburuk pemahaman siswa terhadap matematika itu sendiri. Selain faktor kecemasan ada faktor lain yang tidak kalah penting dalam penalaran matematika, yaitu faktor gender.

Kimura dan Hampson dalam Jensen (2011:46) menyatakan bahwa laki-laki dan perempuan memiliki cara yang sangat berbeda dalam mendekati dan menyelesaikan masalah. Khusus dalam pembelajaran matematika. Kruteski dalam (Nafi'an, 2011:573) menyatakan laki-laki lebih unggul dalam penalaran, sedangkan perempuan lebih unggul dalam ketepatan, ketelitian, kecermatan, dan keseksamaan berpikir. Perbedaan gender tentu menyebabkan perbedaan fisiologis dan psikologis antara laki-laki dan perempaun. Sehingga siswa laki-laki dan perempuan tentu memiliki banyak perbedaan dalam belajar.

Perbedaan gender selain mempengaruhi cara belajar juga mempengaruhi kecemasan matematika. Furner dan Duffy (2002:69) mengemukakan bahwa salah satu faktor yang dapat menimbulkan kecemasan matematika, adalah faktor gender. Hal

\section{METODE PENELITIAN}

Metode penelitian yang digunakan dalam penelitian ini adalah kausal komperatif atau ex post facto. Desain penelitian yang digunakan adalah desain two factorial dengan variabel bebas kecemasan matematika dan gender serta dengan variabel terikat kemampuan penalaran adaptif matematika.

Penelitian ini dilaksanakan di SMP Negeri 2 Kendari yang terletak di Jl. DR. Moh. Hatta. No. 61B Kendari, waktu pelaksanaannya dilakukan pada semester genap Tahun Ajaran 2016/2017, dari tanggal 22 April Sampai dengan 29 April 2017. tersebut disebabkan karena perbedaan cara berpikir antara laki-laki dan perempuan. Peneliti terdahulu menyatakan perbedaan cara berpikir antara laki-laki dan perempuan dipengaruhi oleh keadaan struktur fisik dan biologis otak yang berbeda, yang akibatnya dapat menimbulkan perbedaan prilaku, pengembangan, dan pengolahan kognitif (Jensen, 2011:41). Perbedaan-perbedaan tersebut akan mengakibatkan cara yang berbeda dalam menyelesaikan sebuah masalah serta mengolah rasa cemas.

Perbedaan-perbedaan yang terdapat pada laki-laki dan perempuan tentu menyebabkan perbedaan pola pikir dan perbedaan cara menghadapi berbagai permasalahan dalam belajar. Sehingga laki-laki dan perempuan tentu memiliki banyak perbedaan dalam belajar matematika.

Maccoby \& Jacklyn dalam Sukayasa (2012) mengatakan laki-laki dan perempuan mempunyai perbedaan kemampuan antara lain sebagai berikut:

1. Perempuan mempunyai kemampuan verbal lebih tinggi dari pada laki-laki.

2. Laki-laki lebih unggul dalam kemampuan visual spatial (penglihatan keruangan) daripada perempuan.

Populasi dalam penelitian ini adalah seluruh siswa kelas VIII SMP Negeri 2 Kendari yang berjumlah 373 siswa. Sampel yang digunakan sebanyak 120 siswa.Teknik sampling yang digunakan dalam penelitian ini adalah purposive sampling, yaitu tehnik pengambilan sampel dari populasi dengan pertimbagan calon sampel diajar dengan guru yang sama dan mempunyai karakteristik yang sama. Untuk menjamin keterwakilan dari masing-masing sampel maka dilanjutkan dengan teknik stratified random sampling, yaitu teknik pengambilan sampel secara acak dari populasi di mana populasinya 
dibagi-bagi terlebih dahulu menjadi kelompok yang relatif homogen (stratum).

Instrumen yang digunakan dalam penelitian ini adalah instrumen kecemasan matematika dan instrumen kemampuan penalaran adaptif matematika. Instrumen yang digunakan untuk mengukur tingkat

\section{HASIL PENELITIAN}

Deskripsi data kecemasan matematika antara siswa laki-laki dan kecemasan matematika adalah lembar kuesioner. Instrumen tes berbentuk uraian sebanyak 4 nomor untuk mengukur kemampuan penalaran adaptif matematika siswa pada pokok bahasan Geometri bangun datar (Lingkaran).

siswa perempuan dapat dilihat pada Tabel 1 berikut ini.

Tabel 1. Deskripsi Data Hasil Kuesioner Kecemasan Matematika Antara Siswa LakiLaki Dengan Siswa Perempuan

\begin{tabular}{lll}
\hline \multicolumn{1}{c}{ Analisis Deskriptif } & \multicolumn{1}{c}{ Siswa Laki-laki } & \multicolumn{1}{c}{ Siswa Perempuan } \\
\hline Mean & 107,64 & 116,27 \\
Standar Deviasi & 16,78 & 18,71 \\
\hline
\end{tabular}

Hasil dari tabel diatas bahwa siswa laki-laki memiliki tingkat menunjukkan bahwa nilai rata-rata kecemasan yang lebih tinggi dari pada kecemasan siswa laki-laki lebih rendah dari pada siswa peremuan. Ini berarti perempuan.

Tabel 2. Deskripsi Data Kemampuan Penalaran Adaptif Matematika

\begin{tabular}{clll}
\hline \multirow{2}{*}{ Kategori Kecemasan } & \multicolumn{1}{c}{ Statistika } & $\begin{array}{c}\text { Gender } \\
\text { Laki-Laki }\end{array}$ & \multicolumn{1}{c}{ Perempuan } \\
& $\mathrm{N}$ & 10 & 14 \\
Rendah & Mean & 80 & 83,21 \\
& Standar Deviasi & 10,54 & 11,03 \\
& $\mathrm{~N}$ & 33 & 35 \\
\multirow{2}{*}{ Sedang } & Mean & 50,91 & 58,29 \\
& Standar Deviasi & 16,79 & 12,42 \\
& N & 17 & 11 \\
\multirow{2}{*}{ Tinggi } & Mean & 40,59 & 39,09 \\
& Standar Deviasi & 9,50 & 8,61 \\
& N & 60 & 60 \\
Total & Mean & 52,83 & 60,58 \\
& Standar Deviasi & 19,10 & 18,41 \\
Total & N & 120 & \\
Keseluruhan & Mean & 56,71 & \\
& Standar Deviasi & 19,08 & \\
\hline
\end{tabular}

\footnotetext{
Hasil dari tabel di atas menunjukkan bahwa nilai rata-rata kemampuan penalaran adaptif matematika siswa lakilaki lebih rendah dari pada siswa perempuan secara. Ini berarti bahwa siswa perempuan memiliki kemampuan penalaran adaptif matematika lebih baik

dari pada siswa laki-laki.Melihat secara keseluruhan rata-rata kemampuan penalaran adaptif siswa yaitu 56,71 masih berada dibawah KKM matematika yaitu 72. Ini berarti bahwa kemampuan penalaran adaptif matematika masih rendah.
} 
Tabel 3. Uji Perbedaan Rata-rata Kemampuan Penalaran Adaptif Matematika Siswa Laki-laki dan Siswa Perempuan

\begin{tabular}{|c|c|c|c|c|c|c|c|c|}
\hline \multicolumn{9}{|c|}{ Independent Samples Test } \\
\hline & & \multicolumn{7}{|c|}{ t-test for Equality of Means } \\
\hline & & \multirow[b]{2}{*}{$t$} & \multirow[b]{2}{*}{ df } & \multirow[b]{2}{*}{ Sig. (2-tailed) } & \multirow{2}{*}{$\begin{array}{c}\text { Mean } \\
\text { Difference }\end{array}$} & \multirow{2}{*}{$\begin{array}{l}\text { Std. Error } \\
\text { Difference }\end{array}$} & \multicolumn{2}{|c|}{$\begin{array}{l}95 \% \text { Confidence } \\
\text { Interval of the } \\
\text { Difference }\end{array}$} \\
\hline & & & & & & & Lower & Uppel \\
\hline \multirow[t]{2}{*}{ KPAM } & $\begin{array}{l}\text { Equal variances } \\
\text { assumed }\end{array}$ & -2.26 & 118 & .025 & -7.750 & 3.425 & -14.532 & -.968 \\
\hline & $\begin{array}{l}\text { Equal variances } \\
\text { not assumed }\end{array}$ & -2.26 & 117.843 & .025 & -7.750 & 3.425 & -14.532 & -.968 \\
\hline
\end{tabular}

Hasil analisis pada Tabel 3 menunjukkan bahwa nilai t yang diperoleh sebesar $-2,26$ dan $\operatorname{sig}(1-$ tailed $)=$ $P_{\text {value }} / 2$ adalah 0,012 . Nilai signifikansi tersebut lebih kecil dari taraf signifikansi $\alpha=0,05$ yang ditetapkan, sehingga kesimpulan hipotesis menolak $H_{0}$. Ini berarti bahwa ada perbedaan rata-rata kemampuan penalaran adaptif matematika antara siswa laki-laki dengan siswa perempuan.

Tabel 4. Perubahan Rata-rata Kemampuan Penalaran Adaptif Matematika Untuk Setiap Perubahan Rata-rata Kecemasan Matematika

\begin{tabular}{|c|c|c|c|c|c|c|}
\hline \multicolumn{7}{|c|}{ Coefficients $^{a}$} \\
\hline \multirow{2}{*}{\multicolumn{2}{|c|}{ Model }} & \multicolumn{2}{|c|}{ Unstandardized Coefficients } & $\begin{array}{l}\text { Standardized } \\
\text { Coefficients }\end{array}$ & \multirow[b]{2}{*}{ t } & \multirow[b]{2}{*}{ Sig. } \\
\hline & & $B$ & Std. Error & Beta & & \\
\hline 1 & (Constant) & -43.841 & 5.627 & & -7.792 & .000 \\
\hline & Kecemasan & .898 & .050 & .857 & 18.103 & .000 \\
\hline
\end{tabular}

a. Dependent Variable: KPAM

Berdasarkan pada Tabel 4 diperoleh bahwa nilai sinifikan $=0,000$ lebih kecil dari nilai $\alpha=0,05$. Ini berarti ada pengaruh kecemasan matematika terhadap kemampuan penalaran adaptif matematika. nilai konstanta $\beta_{0}$ sebesar $-43,841$ dan nilai koefisien regresinya $\left(\beta_{1}\right)$ sebesar 0,898. Dari angka tersebut dapat dibuat suatu persamaan regresi yaitu : $\hat{Y}=$ $-43,841+0,898 X$. Persamaan tersebut menginterpretasikan bahwa jika kecemasan matematika memberikan pengaruh positif terhadap kemampuan penalaran adaptif matematika dan sebaliknya. Ini berarti bahwa nilai koefisien regresi sebesar 0,898 menginterpretasikan bahwa jika skor kecemasan matematika mengalami kenaikan sebesar 1 satuan maka kemampuan panalaran adaptif matematika akan meningkat sebesar 0,898. Dimana semakin tinggi skor kecemasan matematika maka semakin rendah tingkat kecemasan matematika sehingga semakin tinggi nilai kemampuan penalaran adaptif matematika dan sebaliknya, semakin rendah skor kecemasan matematika maka semakin tinggi tingkat kecemasan matematika sehingga semakin rendah nilai kemampuan penalaran adaptif matematika. 
Tabel 5. Uji Regresi Linear Berganda Pengaruh Kecemasan Matematika dan Gender Secara Simultan Terhadap Kemampuan Penalaran Adaptif Matematika

\begin{tabular}{|c|c|c|c|c|c|c|}
\hline \multicolumn{7}{|c|}{ ANOVA $^{a}$} \\
\hline \multicolumn{2}{|c|}{ Model } & $\begin{array}{l}\text { Sum of } \\
\text { Squares }\end{array}$ & df & Mean Square & $\mathrm{F}$ & Sig. \\
\hline \multirow[t]{3}{*}{1} & Regression & 31855.167 & 2 & 15927.584 & 162.475 & $.000^{\mathrm{b}}$ \\
\hline & Residual & 11469.625 & 117 & 98.031 & & \\
\hline & Total & 43324.792 & 119 & & & \\
\hline \multicolumn{7}{|c|}{ a. Dependent Variable: KPAM } \\
\hline \multicolumn{7}{|c|}{ b. Predictors: (Constant), Gender, Kecemasan } \\
\hline
\end{tabular}

Berdasarkan Tabel 5 di atas menunjukkan bahwa nilai signifikan $=$ 0,000 lebih kecil dari pada nilai $\alpha=0,05$. Ini berarti ada pengaruh kecemasan matematika dan gender secara simultan terhadap kemampuan penalaran adaptif matematika siswa.

Tabel 6. Uji Regresi Linear Berganda Pengaruh Kecemasan Matematika dan Gender Secara Parsial Terhadap Kemampuan Penalaran Adaptif Matematika

\begin{tabular}{|c|c|c|c|c|c|c|}
\hline \multicolumn{7}{|c|}{ Coefficients $^{a}$} \\
\hline \multirow{2}{*}{\multicolumn{2}{|c|}{ Model }} & \multicolumn{2}{|c|}{ Unstandardized Coefficients } & \multirow{2}{*}{$\begin{array}{c}\begin{array}{c}\text { Standardized } \\
\text { Coefficients }\end{array} \\
\text { Beta }\end{array}$} & \multirow[b]{2}{*}{$\mathrm{t}$} & \multirow[b]{2}{*}{ Sig. } \\
\hline & & $B$ & Std. Error & & & \\
\hline \multirow[t]{3}{*}{1} & (Constant) & -43.862 & 7.016 & & -6.251 & .000 \\
\hline & Gender & .008 & 1.861 & .000 & .005 & .996 \\
\hline & Kecemasan & .898 & .051 & .858 & 17.509 & .000 \\
\hline
\end{tabular}

Dari Tabel 4.17 pada baris gender menunjukkan nilai Sig. variabel gender sama dengan 0,996 lebih besar dari nilai $\alpha=0,05$ dan pada baris kecemasan menunjukkan nilai Sig. variabel

\section{PEMBAHASAN}

Hasil uraian-uraiananalisis deskriptif sejalan dengan pengamatan peneliti saat pengambilan data kemampuan penalaran adaptif matematika siswa di lapangan. Dimana pada saat tes banyak siswa berwajah tegang, ada beberapa yang sedikit gelisah lihat kekiri-kekanan bahkan kebelakang, ada yang sambil memegang kepala, ada juga yang sempat berkomentar bahwa "soalnya susah" karena kalimat soal yang dilihat panjang tanpa membacanya terlebih dahulu dan beberapa siswa berkomentar bahwa "soal-soalnya seperti bukan matematika yang Pengaruh Kecemasan Matematika Dan Gender Terhadap Kemampuan Penalaran Adaptif Matematika Siswa SMP Negeri 2 Kendari (Rahmat Wijaya, Fahinu, Ruslan) kecemasan sama dengan 0,000 lebih kecil dari nilai $\alpha=0,05$. Ini berarti bahwa hanya faktor kecemasan matematika yang memberikan pengaruh.

menghitung". Dilain sisi hanya sedikit siswa yang merasa santai dan fokus mengerjakan soal. Beberapa siswa ini kadangkala bertanya mengenai maksud dari soal-soal yang di teskan. Ada siswa yang bertanya "pak!, soal nomor 1 sampai 3 cuma ditulis pendapatnya kita ?, tidak usah ada perhitungan ?", ada juga yang bertanya "bisakah saya mulai kerjakan dulu soal nomor 4, nomor 4 itu lebih mudah karena cuma menghitung", ada juga yang bertanya " itu soal nomor 3 ada dua kesimpulan ditulis, mau di kasih alasan satu-satu atau yang terakhir saja ?". 
gejala gejala yang timbul dilapangan saat melakukan tes kemampuan penalaran adaptif mateatika dapat di asumsikan bahwa siswa tidak mampu fokus dalam megerjakan soal jika ia mengalami kecemasan, sementara siswa yang terlihat santai dan fokus mengerjakan soal antusias bertannya untuk menyelesaikan soal tampa adanya rasa takut.

Gejala kecemasan yang muncul terlihat lebih banyak dialami oleh siswa laki-laki dibanding siswa perempuan. Dimana sebagian besar siswa perempuan lebih terlihat santai dibandingkan siswa laki-laki. Hal ini sejalan dengan hasil perhitungan saat kategorisasi kuesioner, dimana ada 17orang siswa laki-laki berkecemasan tinggi dengan rata-rata nilai 40,59 dan 11 orang siswa perempuan berkecemasan tinggi dengan rata-rata nilai 39,09 yang tidak berbeda jauh. Ada 10 orang siswa laki-laki berkecemasan rendah dengan rata-rata nilai 80 dan ada 14 siswa perempuan berkecemasan rendah dengan rata-rata nilai 83,21 yang juga tidak berbeda jauh.

Setelah melakukan pemeriksaan dan pengecekan kembali hasil tes kemampuan penalaran adaptif matematika siswa. Siswa yang tenang dan berkonsentrasi atau siswa dengan kecemasan rendah memperoleh hasil yang berbeda dengan siswa yang gelisah dan sulit berkonsentrasi atau siswa dengan kecemasan tinggi. Dimana siswa dengan kecemasan yang tinggi tidak jarang yang mampu menyelesaikan jawaban satu soal dengan utuh atau lengkap dan banyak yang kurang mampu mengidentifikasi apa yang dimaksud dari soal, sementara untuk siswa dengan kecemasan rendah mampu mengidentifikasi apa yang dimaksud soal dan mampu menyelesaiakan satu soal secara utuh dan lengkap. Antara siswa laki-laki dan perempuan juga menunjukkan perbedaan dalam menyelesaikan soal, dimana siswa lakilaki lebih simpel dalam melakukan penyelesaian dan memberikan jawaban langsung ke inti permasalahan, sementara untuk siswa perempuan lebih sistematis dan terperinci menuliskan langkahlangkah dalam melakukan penyelesaian

Perbedaan-perbedaan yang terdapat pada laki-laki dan perempuan tentu menyebabkan perbedaan pola pikir dan perbedaan cara menghadapi berbagai permasalahan dalam belajar. Dikatakan bahwa laki-laki lebih unggul dalam penalaran sementara perempuan lebih unggul dalam ketepatan, kecermatan dan keseksamaan berpikir. Pada lain sisi siswa laki-laki unggul dalam mengolah pengetahuan yang bersifat visual sementara perempuan unggul dalam pengolahan emosi dan pengetahuan yang bersifat verbal. Hal ini mengindikasikan pada jawaban siswa laki-laki yang berkecemasan rendah pada nomor 1 dan 4 menunjukkan jawaban-jawaban benar dengan cara penyelesaian langsung ke inti permasalahan tanpa banyak menuliskan kata-kata keterangan, sementara untuk jawaban siswa perempuan yang berkecemasan rendah pada nomor 1 dan 4 menunjukkan jawaban-jawaban benar dengan cara penyelesaian yang banyak menggunakan rincian kata-kata atau kalimat untuk memperjelas jawabannya. Pada siswa laki-laki dengan tingkat kecemasan tinggi pada nomor 1 dan 4 menunjukkan jawaban yang kurang tepat dimana pada nomor 1 siswa mencoba memberikan gambaran tapi tidak mampu memberikan sebuah kata-kata atau kalimat untuk menggambarkan masalah pada nomor 1 dan untuk nomor 4 siswa ini mampu menemukan pola penyelesaian namun tidak mampu melaksanakan operasi atau proses pemecahan masalah dengan benar, di asumsikan bahwa ini terjadi karena kecemasan yang ada pada saat proses pembelajaran konsep atau penerimaan materi sehingga kurangnyainformasi yang diperoleh pada masa lalu. Pada siswa perempuan dengan kecemasan tinggi pada nomor 1 dan 4 menunjukkan jawaban yang kurang tepat 
dimana pada nomor 1 tidak seperti siswa laki-laki yang berkecemasan tinggi, siswa ini memberikan jawaban dengan kata-kata atau kalimat namun kalimat-kalimat masih mengandung beberapa kesalahan, untuk nomor 4 siswa ini mampu menemukan pola dengan banyak kata-kata keterangan dan gambar secara visual namun masih mengandung kesalahan, pada gambar terlihat garis lurus yang membagi dua taman, sementara pada soal diterangkan bahwa taman terbagi dua oleh garis yang menyerupai huruf $\mathrm{S}$, hal ini bisa saja terjadi karena kurangnya kemampuan untuk mengolah informasi secara visual dan adanya kecemasan yang terjadi sehingga kurangnya penerimaan informasi dimasa lalu.

Hasil analisis inferensial menunjukkan bahwa adanya perbedaan pengaruh kemampuan penalaran adaptif matematika siswa yang ditinjau dari tingkat kecemasan dan gender di SMP Negeri 2 Kendari. Hasil uji $t$ mmenunjukkan adanya perbedaan rata-rata kemampuan penalaran adaptif matematika antara siswa laki-laki dan siswa perempuan. Ditinjau dari tingkat kecemasannya dengan menggunakan

\section{KESIMPULAN DAN SARAN}

Berdasarkan hasil analisis dan pembahasan hasil penelitian, diperoleh simpulan penelitian sebagai berikut :

1. Adanya perbedaan rata-rata kecemasan antara siswa laki-laki dan siswa perempuan, dimana siswa laki-laki memiliki tingkat kecemasan matematika lebih tinggi daripada siswa perempuan

2. Kemampuan penalaran adaptif siswa berdasarkan gender, dimana kemampuan penalaran adaptif siswa perempuan lebih baik daripada kemampuan penalaran adaptif siswa laki-laki, berdasarkan tingkat kecemasan semakin tinggi kecemasan matematika siswa maka semakin rendah kemampuan penalaran adaptif statistik regresi linear sederhana, kecemasan matematika memberikan pengaruh positif dimana semakin tinggi skor kecemasan maka semakin rendah tingkat kecemasan matematikanya, sehingga semakin tinggi tingkat kemampuan bernalarnya dalam menyelesaikan masalah. Hasil statistik regresi linear berganda menunjukkan adanya pengaruh kecemasan matematika dan gender secara simultan terhadap kemampuan penalaran adaptif matematika siswa.

Berdasarkan uraian di atas, temuan penelitian mengungkapkan bahwa gender mempunyai pengaruh dalam cara berpikir atau bernalar seseorang untuk memecahkan suatu masalah walaupun perbedaan yang di timbulkan antara lakilaki dan perempuan tidak terlalu jauh berbeda. Sementara cara berpikir dan bernalar dengan keadaan tingkat kecemasan yang berbeda cukup mempengaruhi seseorang untuk memecahkan suatu masalah, dimana semakin tinggi tingkat kecemasan seseorang maka semakin sulit pula ia menemukan pola pikir dalam memecahkan suatu masalah.

matematikanya dan sebaliknya. Secara keseluruhan kemampuan penalaran adaptif siswa masih rendah yaitu dibawah kriteria ketuntasan minimal.

3. Adanya perbedaanrata-rata kemampuan penalaran adaptif matematika antara siswa laki-laki dengan siswa perempuan. Sehingga dapat dikatakan bahwa ada perbedaan kemampuan penalaran adaptif matematika ditinjau dari gender.

4. Adanya pengaruh kecemasan matematika terhadap kemampuan penalaran adaptif matematika. Dimana jika skor kecemasan matematika meningkat maka nilai kemampuan penalaran adaptif matematika akan ikut meningkat, dalam hal ini semakin 
tinggi skor kecemasan matematika maka semakin rendah tingkat kecemasan matematika siswa dan sebaliknya.

5. Terdapat pengaruh kecemasan matematika dan gender secara simultan terhadap kemampuan penalaran adaptif, akan tetapi secara parsial hanya faktor kecemasan matematika yang berpengaruh terhadap kemampuan penalaran adaptif.

Berdasarkan pembahasan dan kesimpulan penelitian, terdapat beberapa saran yang perlu di tuliskan peneliti sebagai berikut :

1. Kepada para pendidik pada umumnya untuk senantiasa memperhatikan dan menjaga emosional psikologi siswa khususnya tingkat kecemasannya agartetap stabilterhadap mata pelajaran atau materi yang disampaikan agar tidak mempengaruhi buruknya produktivitas berpikir logis dalam memecahkan masalah, seperti sikap pendidik yang ramah dan menyenangkan serta sifat materi yang sesuai kemampuan dan tidak membebankan siswa.

2. Kepada para guru bidang studi matematika harus senantiasa memberikan contoh dan permasalahanpermasalahan matematika yang konteks ataupun nonrutin yang tidak hanya sekedar menghitung dan mengoperasikan angka-angka tetapi juga perlu adanya permasalahan seperti

\section{DAFTAR PUSTAKA}

Ashcraft, Mark H. 2002. Math Anxiety: Personal, Educational, and Cognitive Consequences, Artikel Ilmiah, Vol.11, No.5, Ohio: Department of Psychology. [Online]. Tersedia:

http://www.mccc.edu/ jenningh/Cou rses/documents/math_anxiety.pdf [22 Desember 2016]. membuktikan, memberi alasan dan memberikan kesimpulan dari suatu pernyataan. Karena esensi ilmu matematika sendiri itu adalah ilmu yang mempelajari pola, sementara berhitung serta mengoperasikan angka hanyalah bagian dari cara matematika mengajarkan pola.

3. Kepada para peneliti selanjutnya, baiknya melakukan penelitian analisis yang bersifat kualitatif karena belum ditemukannya mana faktor sebab dan mana faktor akibat antara kecemasan matematika dengan kemampuan penalaran adaptif matematika, atau belum diketahuai apakah kecemasan matematika yang mengakibatkan nilai tes penalaran adaptif rendah atau sifat materi atau soal tes kemampuan penalaran adaptif yang mengakibatkan nilai tes penalaran adaptif matematika rendah. Jika mengambil penelitian kausal komparatif sebaiknya mengambil sampel yang lebih banyak lagi jika nantinya sampel tersebut akan dibagi menjadi subsampel, agar subsampel bisa lebih mewakili populasi. Jika mengambil penelitian eksperimen sebaiknya mengambil model ataupun metode yang mampu mereduksi emosi khususnya kecemasan dan memperhatikan kemampuan model atau metode yang digunakan agar mampu meningkatkan kemampuan penalaran matematika siswa.

Desmita. 2010. Psikologi Perkembangan Peserta Didik. Bandung: PT. Remaja Rosdakarya.

Dzulfikar, Ahmad. 2013. Studi Literatur: Pembelajaran Kooperatif dalam Mengatasi Kecemasan Matematika dan Mengembangkan Self Efficacy Matematis Siswa. Prosiding SeminarNasional Matematika dan pendidikan Matematika. FMIPA 
UNY. ISBN : $978-979-16353-9$ -4 .

Furner, Joseph M. dan Duffy, Mary Lou. 2002. Equity for All Students in the NewMillenium: Disabling Math Anxiety, Artikel ilmiah U. LDOn.[Online]. Tersedia: http://ourmathresource.weebly.com/ uploads/5/3/4/8/53486121/disabling _math_anxiety.pdf [28 Februari2017]

Hayat, B. dan Suhendra Y. 2010. Benchmark Internasional Mutu Pendidikan. Jakarta: Bumi Aksara.

Hudojo, H. 2005. Pengembangan Kurikulum dan Pembelajaran Matematika. Malang : UNM.

Ibrahim. 2011. Peningkatan Kemampuan Komunikasi, Penalaran, danPemecahan Masalah Matematis serta Kecerdasan Emosional MelaluiPembelajaran Berbasis Masalah Pada Siswa Sekolah Menengah Atas. Disertasi Doktor pada SPs UPI. Bandung: Tidak Diterbitkan.

Indarwati, Dona Suci. 2012. Identifikasi Kesalahan Siswa dalam Menyelesaikan Soal Cerita MatematikaSistem Persamaan Linear Dua Variabel Berdasarkan Kriteria Watson di Kelas VIII A SMP Yayasan Taman. Surabaya: Skripsi Prodi Pend. Matematika IAIN Sunan Ampel.

Jensen, Eric. 2011 Pembelajaran Berbasis Otak. Jakarta: Indeks.

Kilpatrick Jeremy, Jane Swafford. \& Bradford Findell. 2001. Adding It Up: HelpingChildren Learn Mathematics. Washington DC: National Academy Press.

Nafi'an M. I. 2011. Kemampuan Siswa Dalam Menyelesaikan Soal Cerita Ditinjau Dari Gender Di Sekolah Dasar. Prosiding Seminar Nasional
Matematika dan

PendidikanMatematika dengan tema "Matematika dan Pendidikan Karakter dalam Pembelajaran", di Jurusan Pendidikan Matematika FMIPA UNY. ISBN: 978-97916353-6-3.

Sobel dan Malestky. 2004. Pembelajaran Matematika. Jakarta: Erlangga

Subanindro. 2012. Pengembangan Perangkat Pembelajraan Trigonometri Berorientasikan Kemampuan Penalaran dan Komunikasi Matematik Siswa SMA. Prosiding ISBN: 978-979-16353-8-7

Sukayasa. 2012. Pengembangan Model Pembelajaran Berbasis Fase-Fase Polya untuk Meningkatkan Kompetensi Penalaran Siswa SMP dalam Memecahkan Masalah Matematika.[Online]. Tersedia: http://jurnal.untad.ac.id /jurnal/index.php

/AKSIOMA/article/view/1278/97

[11 Januari 2017].

Tambunan, Hardi. 1999. Kemampuan Siswa Menyelesaikan Soal Cerita Pokok Bahasan Trigonometri dengan Strategi Heuristik. Surabaya:Tesis Pascasarjana UNESA

Wicaksono, Arief B. dan Saufi M. 2013. Mengolah Kecemasan Siswa dalam Pembelajaran Matematika, Prosiding Seminar Nasional Matematika dan Pendidikan Matematika, Jurusan Pendidikan Matematika FMIPA UNY. ISBN : $978-979-16353-9-4$.

Zakariah, Effandy dan Nurdin, Norazah M. 2008. The Effects of Mathematics Anxiety on Matriculation Studentsas Related to Motivation and Achievement. Eurasia Journal of Mathematics. 
Science \& Technology Education.

4(1): 27-30. 